\title{
Una teoría dieciochesca de la novela y algunos conceptos de poética
}

Jesús PÉRez Magallón

Universidad de Barcelona

A don Antonio Mestre, eximio erudito

Ya no puede afirmarse sin rubor que la bibliografía mayansiana sea exigua. Sin embargo, y pese a los enormes esfuerzos desplegados en los últimos tiempos, algunas facetas del quehacer intelectual de Mayans han quedado en un muy discreto segundo plano. Entre ellos, las ideas literarias son sin duda una de las que destacan con mayor relieve, por resultar de superior violencia e injusticia hacia lo que fue preocupación y amor indesmayable del valenciano.

La reflexión literaria de Mayans se enmarca con perfecta armonía en el contexto dieciochesco, por un lado, y, por el otro, en el de una sólida y amplia formación clasicista. La labor mayansiana, compaginando la investigación con la pedagogía, se recorta a lo largo de la centuria $-\mathrm{y}$ ya desde la década de los veinte-con tonos peculiares por una persistente reivindicación de los valores más acendradamente clásicos. Una falta de originalidad consciente y deseada junto a atisbos innovadores de enorme influencia caracterizan el trabajo de casi un siglo.

Las limitaciones de un artículo no permiten siquiera rozar asuntos de tanta importancia como el esfuerzo por restaurar la prosa castellana y las características que debe reunir el lenguaje, el pensamiento estético, la labor historiográfico-literaria, el peso de la misma en el nacimiento del concepto de Siglo de Oro o la ristra de ediciones surgidas bajo el 
impulso o con el esfuerzo personal de Mayans, por mencionar sólo algunos ${ }^{1}$.

En este umbral puede asegurarse, no obstante, que las ideas literarias del valenciano constituyen -en su campo y con sus rasgos definidores - uno de los pilares insustituibles sobre los que se erige el edificio del pensamiento y la literatura ilustrados.

\section{Una teoría de la novela}

En el marco general de la preocupación mayansiana por los problemas de la prosa, haciendo frente a los enrevesamientos poetizantes, a la oscuridad, extravagancia e ineficacia del lenguaje acarreado desde el barroco más depravado, y en el más concreto de su Vida de Miguel de Cervantes, acomete Mayans, sobre la base de las dedicatorias de Lope en sus novelas a Marcia Leonarda, y de algunos escritos cervantinos, singularmente el «Prólogo» a las Novelas Ejemplares y los capítulos 47 y 48 de la primera parte del Quijote, el intento de dar forma a lo que puede llamarse una «teoría de la novela» de corte clasicista ${ }^{2}$.

Rebatiendo a Avellaneda, que en el «Prólogo» a su Quijote apócrifo había afirmado en tono crítico que $L a$ Galatea y demás novelas de Cervantes no eran sino comedias en prosa, Mayans sostiene que no puede considerarse extraño que las comedias se escriban en prosa, pues, en su opinión, así se escribieron las griegas y latinas, ya que el yambo es pie cuyo ritmo se aproxima muchísimo al de la prosa, y que en castellano no es nada nuevo, teniendo como ejemplos singulares la Celestina y la Eufrosina; tampoco ve anómalo que las novelas sean comedias, puesto que la novela, al ser una fábula, forzosamente ha de ser de alguna de las especies conocidas de fábula, parentesco, por otra parte, que ya había señalado Lope en el «Prólogo» a La desdicha por la honra. Así, puesto que

1 He intentado desarrollar la diversidad del ideario mayansiano en mi tesis inédita, En torno a las ideas literarias de Mayans, Facultad de Filología, Universidad de Barcelona, 1985.

2 Sin pretender entrar en más detalles, apuntaré tan sólo que la Lettre de l'origine des Romans, de P.D. Huet, se encuentra en el punto de arranque de algunas opiniones mayansianas que aquí se tratan. 
toda fábula es ficción, i toda ficción es narración o de cosas que no sucedieron pero fueron possibles, o de cosas que ni sucedieron ni fueron possibles ${ }^{3}$,

divide las narraciones entre aquellas que tratan de cosas meramente posibles y las que tratan de cosas imposibles. La narración de cosas posibles será parábola si se atiende a la semejanza y propósito entre lo fingido y lo que se quiere persuadir; y novela si se atiende sólo a la invención. La narración de cosas imposibles será apólogo porque aunque la hipótesis sea imposible, una vez supuestas sus partes como existentes:

se deven guardar con verosimilitud la propiedad i costumbres de las personas fingidas, siguiendo en todo la naturaleza de las $\operatorname{cosas}^{4}$.

La ficción de la novela se compone:

o de partes meramente possibles, como casi todas las que ai escritas, o de sucessos verdaderos pero que no tuvieron el enlace i conseqüencia que dice el autor, porque si no sería historia o relación verdadera ${ }^{5}$.

Si la ficción de cosas posibles propone la imitación de una idea ilustre, perfecta, engrandecedora y la mejor que pueda imaginarse, será epopeya o tragedia. Para Mayans, tanto es epopeya la Ilíada como el Quijote, pues:

si la Ilíada es una fábula heroica escrita en verso, la Novela de Don Quijote lo es en prosa, que la épica (como escrivió Cervantes) tan bien puede escrivirse en prosa como en verso ${ }^{6}$.

Idea cervantina que retoma Mayans, y cuyo parentesco con la conocida definición que da Fielding de la novela como «comic epic poem in prose ${ }^{7}$ es fácil notar. Llega don Gregorio a escribir estas palabras de estupenda modernidad: «yo no diferencio a Aquiles airado de Don Quijote loco» ${ }^{8}$. Aunque no deslinda, como hará Lukacs, epopeya de novela, situando los orígenes de ésta en la degradación y muerte de aquélla, el reconocimiento del vínculo entre epopeya y novela, sin tildar al Quijote de epopeya ridícula, hay que valorarlo en su justo término.

3 Gregorio Mayans, Vida de Miguel de Cervantes, Madrid, Espasa-Calpe, 1972, p. 147.

4 Ibid., p. 148.

5 Ibid., p. 149.

$6 \quad$ Ibid., p. 151.

7 Citado en I. Watt, The Rise of the Novel, London, Chatto \& Windus, 1974, p. 249.

8 Gregorio Mayans, Vida de Miguel de Cervantes, p. 151. 
La relación de la novela con la tragedia aparece en los ojos de Mayans con toda nitidez en algunos episodios de Los trabajos de Persiles y Sigismunda, a los que sólo falta «la disposición dramática, coro i aparato scénico» ${ }^{9}$.

Si la ficción de cosas posibles propone:

una idea de la vida civil que sea más practicable, o los defectos de la naturaleza o del ánimo, ahora sea para reprehenderlos, ahora para incitar a su burla 0 imitación, que a esto llega la malignidad del entendimiento humano ${ }^{10}$,

será comedia como la mayoría de las cervantinas, égloga, como La Galatea, sátira como La gitanilla o Rinconete y Cortadillo, entremés, novela sibarítica o milesia, fábula sáltica o romance. En la perspectiva de Mayans, pues, la novela está emparentada con todas las formas canonizadas por la poética clásica. Pero la novela no es sólo epopeya o tragedia, comedia o égloga. La novela, como historia fingida ${ }^{11}$, es algo más, es la posible síntesis de formas y estilos, y el novelista, como diestro inventor:

sabe hacer una agradable mezcla de todas estas especies de fábulas, assí en lo que toca a los caracteres de las personas i costumbres como al estilo, apropiándole al sugeto de que se trata ${ }^{12}$.

En la Rhetórica, volviendo a la novela al referirse a la historia fingida, la definiría como:

una fingida narración de sucesos circunstanciados para instrucción de quien los oye o los lee ${ }^{13}$,

reivindicando de nuevo la prosa como su mejor forma de expresión, y juzgando que este tipo de narración debe ser «admirable, llena de ejemplos instructivos, pura, clara, dulce» ${ }^{14}$, abarcando en el género tanto

9 Ibid., p. 151.

10 Ibid., p. 149.

11 La historia fingida se opone a la historia por cuanto, siguiendo la tradición aristotélica, ésta es para Mayans «relación verdadera de las cosas singulares ya sucedidas en el tiempo en que se escrive», Rhetórica, Valencia, Hdos. Gerónimo Conejos, 1757, II, p. 477.

12 Gregorio Mayans, Vida de Miguel de Cervantes, p. 153.

13 Gregorio Mayans, Rhetórica, II, p. 332.

14 Ibid., II, p. 346. 
el cuento como la novela, pues, como ya había escrito en la Vida de Miguel de Cervantes, citando a Lope, la diferencia entre ambos es simple cuestión de extensión. El diferente desarrollo y amplitud que dedica al tema en una y otra obra es ostensible y, sin duda, está motivado por su diferente carácter y función.

La novela, aunque este término englobe al cuento - desde nuestra óptica más que discutiblemente- y se compagine con el más amplio de historia fingida, tiene una sustantividad propia. Para atribuírsela, Mayans no encuentra otras referencias que las que le aportan las poéticas tradicionales. En éstas se topa con la comedia; pero la novela, siendo comedia, es más que comedia. Y lo mismo puede decirse de la epopeya, tragedia, sátira, égloga, etc. La novela, que se basa en la acción de unos personajes, enriquecida con diferentes episodios, que genera una cronología ficticia propia, es fusión de materiales reales o imaginados, de carácter a la vez cómico, trágico o satírico. Consecuentemente, admite Mayans la presencia - juntos, pero no revueltos- de los estilos más diversos, desde el más elevado al más bajo, y, por tanto, de los lenguajes característicos y apropiados a cada uno de ellos. Apoya el valenciano sus ideas en estas palabras de Cervantes:

Porque la escritura desatada destos libros da lugar a que el autor pueda mostrarse épico, lírico, trágico, cómico, con todas aquellas partes que encierran en sí las dulcísimas i agradables ciencias de la poesía i la oratoria ${ }^{15}$.

Concebida y aceptada como síntesis de formas poéticas escrita en prosa, la novela no puede escapar a las exigencias de principio que tiene cualquier obra: unidad de acción, en el sentido de que los diferentes episodios no se alejen de la acción principal hasta el extremo de difuminarla; verosimilitud; decoro, a pesar de la coexistencia de personajes pertenecientes a esferas sociales opuestas y de actitudes y lenguajes diversos; honestidad; religiosidad, o respeto a la religiosidad; instrucción y deleite. La novela, como los demás géneros poéticos, imita la realidad, la representa. Pero no toda la realidad tal cual es. Lo impúdico, lo obsceno, lo perverso, lo bajo, lo irreligioso, todo eso queda excluido. Realidad embellecida, imitación universal perfeccionadora, se diga con unas o con otras palabras, enfocada hacia el honesto deleite, la instrucción y el fomento de la piedad: ése debe ser el sustrato de la novela.

15 Gregorio Mayans, Vida de Miguel de Cervantes, p. 154. 
No admite Mayans, ni puede admitir, la novela como un género determinado en función de los gustos del vulgo (léase público lector, comprador de libros), como no puede aceptar ese argumento en la pluma del gran Lope para justificar su modo de hacer comedias. Su orgullo de intelectual, bebido directamente en la Introductio ad Sapientiam de Vives, y puesto de manifiesto constantemente a lo largo de su vida y sus escritos, alcanza a formular y aceptar una teoría de la novela de carácter culto, lo que no es poco, y que reaparecerá, enriquecida por su contacto directo con la novelística europea de la época, en Origen, progresos y estado actual de toda la literatura, de Juan Andrés.

- Inserto como está en la estética y teoría literaria del clasicismo grecolatino y renacentista, Mayans no da, ni puede dar, el paso adelante: admitir la autonomía, independencia y superior modernidad de la novela respecto a los demás géneros; reconocer que lo verdaderamente esencial en la novela es el yo del narrador que elabora y reelabora los materiales que desea (o puede) y le convienen a su obra, provengan de donde provengan y tengan el cariz que tengan sea en lo moral, en lo religioso o en lo político; entender la novela —o la literatura de ficción- como expresión, voluntaria o involuntaria, de la interioridad espiritual, afectiva, psicológica o intelectual del escritor, proyectándose sobre la realidad o sobre las fantasías de su mente -en último término o por analogía siempre vinculadas a realidad-; admitir la relatividad o aun insignificancia de nociones como lo verosímil, el decoro, la finalidad didáctica e instructiva, etc. Por otra parte, tampoco es de extrañar. Cervantes no pudo superar en su conciencia su formación clasicista, aunque dejó - gracias a ella, o pese a ella - una obra que indiscutiblemente la desborda, para iluminar al hombre eternamente. Mayans, que tampoco pudo superarla, dejó en este terreno un bosquejo teórico, relevante y pionero en su siglo, aunque luego arrinconado inflexiblemente por la rueda de la Historia.

En otro orden de cosas, Mayans opone, antes que ningún otro, la tradición que encarna el Quijote, y también la Celestina, el Lazarillo, el Guzmán de Alfarache o las Novelas Ejemplares, a la proliferación y penetración de novelas francesas. Es explícito sobre el tema, pero no puede referirse a las novelas publicadas en España, cuyo reducido catálogo puede verse en R. F. Brown o J.F. Montesinos ${ }^{16}$. Probablemente

16 Reginald F. Brown, La novela española, 1700-1850, Madrid, Servicio de Publicaciones del Ministerio de Educación Nacional, 1953; José F. Montesinos, Introduc- 
aluda a las novelas de Furetière, Scarron ${ }^{17}$, Lesage $\mathrm{u}$ otros, que debían de llegar a los libreros madrileños que abastecían la por entonces aún exigua demanda existente. No había llegado todavía el boom novelístico de las dos últimas décadas del siglo, con obras de Marmontel, Mme. de Genlis, Mme. Le Prince de Beaumont, Campe, Richardson o Defoe entre otros. La postura de Mayans tendrá, en este sentido, conspicuos continuadores.

En diferentes lugares de su producción apunta Mayans líneas de comprensión histórica de la evolución y origen de la novela. En la Vida de Miguel de Cervantes se remite a las invasiones bárbaras, y por tanto a las tradiciones germánicas y sajonas, para ubicar el comienzo de la afición a las historias enteramente ficticias, de las que surgirían probablemente las novelas de caballerías, que alcanzarían un notable desarrollo en Francia, y alude a las obras de Turpin o de Monmouth; esa corriente se injertaría en España con la afición de origen árabe a las consejas, cuentos de viejas e historias fabulosas, de las que hay numerosos ejemplos. Lógico resulta, pues, que aquí arraigase el gusto hacia los libros caballerescos más que en ninguna otra parte, y que aquí alcanzase la cima de su arte; lo que, por otro lado, no le impide mostrar su acérrima enemiga hacia tales libros, en la mejor tradición humanista.

En la «Noticia sobre el verdadero autor de la Vida de Justina Díz»», emparenta la obra de López de Úbeda — sin entrar aquí a discutir su aceptación de la creencia de Nicolás Antonio sobre la autoría de fray Andrés Pérez - con otras obras: el Patrañuelo, el Lazarillo y el Guzmán. Aparte de considerar la Atalaya de la vida humana como muy superior a las demás y de juzgar al autor de la Pícara Justina como uno de los introductores de la prosa retorcida, confusa y extravagante juicio suave comparado con el de Menéndez Pelayo-, es de destacar la relación que establece entre esas obras, y que en la Rhetórica le llevará a citar como ejemplos de novela el Lazarillo, el Guzmán y el Quijote. No intentará Mayans establecer o indagar los vínculos que unen esas

ción a una historia de la novela en España en el siglo XIX, Madrid, Castalia, 1983; Ignacio Ferreras, Catálogo de novelas y novelistas españoles del siglo XIX, Madrid, Cátedra, 1979; Teresa Barjau, La novela en España de 1750-1808, Tesis inédita, Facultad de Filología, Universidad de Barcelona.

17 A Scarron lo citará expresamente en la carta que escribe a Voltaire el 14-2-1762, vid. Voltaire's Correspondence, ed. de Th. Besterman, Genève, Institut et Musée Voltaire, 1959, XLVIII, p. 96. 
tres obras, quizá sólo sea el orden cronológico, quizá la calidad de su prosa, quizá la filiación subterránea que - salvando las distancias- existe entre ellas. Por otra parte, es ilustrativa la visión de continuidad que parece indicar el valenciano entre, por ejemplo, la Historia Ethiópica de Heliodoro, (quizás el juicio de Vives lo había alejado de Bocaccio). En el caso de los libros de caballerías, es evidente que éstos surgen de un cierto tipo de ruptura de la tradición. Pero, ¿y el Lazarillo? No hay respuesta, y ya no volverá sobre el tema. Habrán de transcurrir bastantes años antes de que Juan Andrés en su Origen, o Santiváñez, en el «Prólogo» a la traducción de La mala madre de Marmontel, avancen en desbrozar la historia de nuestra novela ${ }^{18}$.

Lo cierto es que la indagación que hace Mayans en este campo — sus apuntes históricos, su aceptación del género como síntesis, su esbozo de teoría de la novela-, sin soslayar sus limitaciones e insuficiencias, pero enmarcada en su constante interés y dedicación a los problemas de la prosa - ausente en Luzán y otros ilustrados-, es un caso notable y excepcional entre los hombres de su tiempo.

Difícil resulta convenir con Montesinos, sin discutir si su catálogo de obras pertenecientes al siglo ilustrado es completo o no, sobre la valoración que hace de la actividad hacia la novela en el dieciocho. Que no hubiera gran producción novelística en la primera mitad del siglo (y aún más tarde o más adelante) no tiene nada de extraño en una época relativamente parca en obras de creación literaria. Pero sí es desafuero evidente acusar a los ilustrados — sin otro matiz- de desinterés absoluto hacia la novela. Las palabras y opiniones de Mayans que he transcrito más arriba, y que aparecen publicadas - no se olvide- en 1737 , revelan todo lo contrario. Y no puede infravalorarse que la Vida de Miguel de Cervantes tiene diversas ediciones a lo largo del siglo, sola o acompañando el texto del Quijote, en español y traducida al francés, al inglés o al alemán, es decir, que no se trata de una obra desconocida, minoritaria o inédita. Incluso los elogios que le dedica fray Martín Sar1784-1799, especialmente el volumen IV; V. M. Santiváñez, en Marmontel, La mala madre, Valladolid, 1788. La obra de Andrés será libro de texto en los Reales Estudios de San Isidro. 
miento ${ }^{19}$ demuestran, al margen del enfrentamiento abierto o soterrado entre Mayans y los diaristas y las Academias, la acogida e inmejorable recepción que tuvo entre la élite intelectual del país y del extranjero.

Lamentarse de perder la tradición del ingenioso hidalgo puede ser un simple desahogo lanzado al vacío. No es solamente un escritor, o el escritor, sino toda una sociedad la que puede - o no puede- recuperar una obra y, con ella, una tradición. Y no se recupera el Quijote sólo por tenerlo -en la República de las Letras no hay barreras ni propiedades nacionales-, ni por imitarlo más o menos burdamente. La novela, como cualquier género literario, ocupa un espacio relativamente preciso en la vida espiritual, cultural, intelectual o lúdica de un pueblo, y juega un papel más o menos determinado en función de las actitudes que adopten, sobre todo, los núcleos intelectuales o literarios del país. Cuando, como es el caso de los ilustrados, el grueso de la intelectualidad está volcada unívocamente a una empresa colectiva de renovación cultural y reforma social, no resulta difícil comprender el poco margen que queda para lo que, desde su mismo pensamiento, se presenta como un simple esparcimiento que, a su manera y en su medida, puede poner en peligro los objetivos esenciales de todo un frente cultural. El planteamiento no deja de ser discutible, pero no se trata de compartirlo, sino de comprenderlo. La actitud de los ilustrados no tiene, además, por qué ser homogénea, ni descarta un posible décalage entre ellos y otros núcleos sociales lo bastante instruidos como para frecuentar ciertas lecturas. La postura ilustrada, sin embargo, es la única referencia viable para entender el conjunto de la situación. En el caso del Quijote, Mayans defiende abiertamente los derechos de la novela, su belleza estilística, su perfección lingüística; sostiene el valor de obras como la Celestina o el Guzmán, pero, ¿basta eso para que haya novelistas? ¿Basta para que una legión de escritores eminentes encuentre en esos libros una tradición que recuperar para su creación literaria? Luzán proponía en 1737 unos criterios nítidos para reorientar la poesía. ¿Generó eso inmediatamente una pléyade de excelentes poetas clasicistas? La escritura no surge de la nada. Pero el vacío no puede achacarse a los ilustrados, ni a la preceptiva que esgrimían en sus denodados esfuerzos por marcar con una nueva orientación la literatura de la época.

19 Se pueden ver en Francisco Brines, «El primer cervantista: Mayans y Siscar (Comentarios a la última edición de su Vida de Cervantes)», Cuadernos Hispanoamericanos, n. ${ }^{\circ} 297,1975$, p. 593. 
La ausencia de la novela realista a lo largo del dieciocho español -si exceptuamos los rasgos perceptibles en Torres Villarroel o en Islarefleja, a la vez, la débil y contradictoria penetración del individualismo surgido al calor de Locke y Descartes, las insuficiencias estructurales de la sociedad española así como sus características ideológico-espirituales.

El realismo narrativo, diferente de los demás géneros no por el objeto que intenta reproducir, sino por la manera en que lo hace, arranca de la preeminencia que el escritor concede no tanto a la realidad en sí como a su experiencia individual de tal realidad ${ }^{20}$. Esta experienciavivencia es única e irrepetible; como hecho intransferible, provoca ansias de innovación y originalidad. No basta, sin embargo, la predisposición del individuo, ni sus ideas sobre el asunto. La novela es inseparable, como todos los géneros, de un estado social e intelectual o espiritual del país. En este sentido, la relación escritor-público - y no en su vertiente crematística - cobra un nuevo carácter, aunque siga siendo esencial. La novela realista exige o crea un cierto tipo de escritores con actitudes mentales que le permiten afrontar el reto de reelaborar la realidad a través de la vivencia; también un estado mental de la nación, o de algunos grupos sociales, dispuestos a acoger la visión no arquetípica que ofrece el escritor.

Siempre se puede acudir a la idea de «genio», pero eso escapa a esta reflexión, o es otra reflexión. Lo cierto es que sólo en Cadalso, como más tarde en Larra y Espronceda, parece apuntarse la posibilidad de una novela realista. Cadalso muere joven; Larra dejaría ese paseo por el amor y la muerte que es El doncel; Espronceda, una novela maestra llamada Sancho Saldaña, por no extenderme más.

Del mismo modo, el auge de la lectura de novelas a fines de siglo no se debe ni el aumento de la influencia francesa ni a la atenuación y relajación de la preceptiva clasicista solamente. Más bien es signo de un cambio de sensibilidad social y, por tanto, de sus intelectuales, consecuencia de una serie de factores coincidentes: cambios sociales, económicos, políticos, influencia de otras culturas que penetran por vías

Discúlpese el término reproducir. Pero, ¿hay otro mejor? Puede verse Ian Watt, The Rise of the Novel, en particular los capítulos I y II, en los que el autor establece una clara asociación entre la evolución del pensamiento filosófico y el surgimiento de la novela realista. Quizá exagerada. 
diferentes, lenta asimilación de actitudes o visiones del mundo que son realidades comunicables y que sólo hacia el ecuador del XIX darán sus frutos (algo esterotipados y discutibles) con La Gaviota y el artículo de Ochoa sobre la novela en $L a$ España ${ }^{21}$. En la presencia, carácter y avance de esos cambios, junto a las posturas de intelectuales y escritores, debe buscar la explicación del fenómeno quien quiera comprender esa ausencia.

\section{Sobre ciertas nociones de poética}

En las líneas anteriores han aparecido obligadamente conceptos clasicistas usados por Mayans sobre ciertos géneros poético-literarios. En su mente anidó la idea de escribir un arte poética. Al menos así lo afirma en su Majansii Vita, al incluir, entre las obras que ha trabajado o está trabajando un «Arte Poética Española que contiene completa la Métrica» ${ }^{22}$. La importancia que concede al arte poética se pone bien de relieve al afirmar que es «Arte la más sublime entre las otras Racionales» ${ }^{23}$. Sin embargo, no parece que llegara a redactarla nunca ${ }^{24}$. Pese a ello, además de las nociones de poética y preceptiva dispersas en la Vida del Miguel de Cervantes y el El Orador Christiano, incluyó un capítulo en su Rhetórica, bajo el epígrafe «De la narración fingida», que muy bien puede tenerse por un brevísimo resumen de poética ${ }^{25}$.

Como ya le ocurriera al escribir El Orador Christiano, donde tuvo que justificarse por entrar él, un laico, en un dominio reservado de siempre a teólogos y eclesiásticos, también aquí se justifica por penetrar en el territorio de la poética:

21 Es Julián Marías quien considera que el artículo de Ochoa, de 1849, refleja la más clara y lúcida visión de lo que es la novela decimonónica; vid., Julián Marías, «Prólogo» a Paul Ilie, La novelística de Camilo José Cela, Madrid, Gredos, 1963.

22 Gregorio Mayans, Gregorii Majansï Vita, ed. de Antonio Mestre, Valencia, Publicaciones del Ayuntamiento de Oliva, 1974, p. 189.

23 Gregorio Mayans, Vida de Publio Virgilio Marón, Valencia, Oficina de los Hnos. Orga, 1795, pp. 45-46.

24 A pesar de que Menéndez Pelayo, en su Historia de las Ideas Estéticas, opina que la dejó escrita, Antonio Mestre, máximo conocedor del tema y la obra mayansiana, no es del mismo parecer.

25 Gregorio Mayans, Rhetórica, I, Libro II, capítulo XII, pp. 302-348. 
No faltará quien reprehenda aver yo tratado de las referidas especies de ficciones, que se han apropiado los que han escrito Artes Poéticas. Pero si bien se observa, la Poética es parte de la Rhetórica: i por esso Aristóteles trató de ella, i de los Poetas en los Libros Rhetóricos, i se valió de sus egemplos ${ }^{26}$,

justificación que es a la vez una reivindicación de los derechos de la retórica sobre la poética, o de la interrelación de ambas. Más interesante resulta la verdadera razón de dicha inserción: tratando, como trata, de ciertas formas de ficción, éstas caen de lleno en el estudio de la retórica, por cuanto, en su opinión, las ficciones se inventaron primeramente en prosa, pero, después, con el fin de hacerlas más armoniosas (y con ello más fácilmente memorizables) fueron sometidas al metro y al ritmo. Por eso no le parecería extraño a Mayans que hubiera habido epopeyas anteriores a Homero escritas en prosa y tal vez perdidas, puesto que tampoco existen numerosas poesías épicas anteriores a los textos homéricos. Lo cierto es que «todo género de Ficción se halla escrito en prosa» ${ }^{27}$, es decir, que además de escribirse en verso puede ser escrito -y lo ha sido- en prosa, aludiendo a los casos de comedias, diálogos, sátiras, apólogos, églogas, etc. Ésa es, pues, la verdadera argumentación de Mayans para entrar en la poética: no existen límites tajantes que permitan afirmar que un género sólo puede escribirse exclusivamente en verso.

Así como Luzán ${ }^{28}$, siguiendo al P. Le Bossu, entiende por fábula la síntesis de acción e instrucción moral, aunque el acento recaiga en el tipo y carácter de la acción, para Mayans la fábula, tras los pasos de Hermógenes ya en la Vida de Miguel de Cervantes, es sinónimo de ficción. En la Rhetórica la definirá como:

Ibid., I, p. 332. Para Roland Barthes, la esencia del pensamiento aristotélico en este campo radica en la escisión de poética y retórica como artes diferenciadas, como puede verse en Investigaciones retóricas I. La retórica antigua, Barcelona, Ed. Buenos Aires, 1982, pp. 16 y ss.

27 Gregorio Mayans, Rhetórica, I, p. 383.

28 No creo preciso señalar que ni por el contexto, ni por el espacio, ni por la finalidad pueden compararse las cuarenta páginas de Mayans con las más de quinientas que Luzán consagra al arte poética. Por ello no he tratado ni de lejos de confrontar sistemáticamente las ideas de uno y otro. Curiosamente, no hay ninguna referencia a Luzán en los trabajos mayansianos. Dejando a un lado las opiniones personales e intelectuales de uno respecto al otro, las obras de ambos no se pueden juzgar en modo alguno como excluyentes. Antes bien, ambas posturas se complementan, más que se oponen. Que las reediciones de La poética y la Rhetórica tengan lugar en 1786 y 1789 no es fruto del azar. 
una oración fingida que con disposición verisímil refiere cierta especie de verdad con el fin de amonestar ${ }^{29}$,

sin especificar si se trata de ficción de cosas posibles o imposibles (introduciendo al mismo tiempo un margen de confusión entre fábula y apólogo), lo que le permitirá establecer sobre esa distinción una clasificación de géneros. Queda fuera de la narración fingida toda narración - sea cual sea su forma y asunto- que trate de temas reales acaecidos, excepto, como indicaba al hablar de la novela, que se integren en una historia fingida sin el orden ni relaciones que tuvieron en la realidad.

Si la narración trata de cosas posibles, se tendrá la epopeya, la tragedia, la égloga, la bucólica, la comedia, el diálogo, la sátira o el entremés; si es de cosas imposibles, el apólogo (lo que entendemos por fábula); si es una mezcla de cosas posibles e imposibles que «se representan en una fingida ordenación de tiempo ${ }^{30}{ }^{3}$, las novelas o historias fingidas.

La epopeya, en palabras de Mayans, es:

una viva representación de las acciones ilustres de Personas insignes en las artes de la paz o de la guerra, con el fin de excitar los ánimos de los oyentes, o de los lectores, a la admiración, i de moverlos a la imitación de tan heroicas virtudes ${ }^{31}$.

Asociada estrechísimamente se encuentra la tragedia, que consiste en la representación de una sola acción ilustre del héroe, imitada con perfección ${ }^{32}$. Llama la atención que el valenciano, familiarizado con la idea de catarsis aristotélica, -como demuestra en la Vida de Miguel de Cervantes o en el Arte de Pintar - prescinde aquí de la purgación de los afectos como función y finalidad de la tragedia, en tanto pone todo su énfasis en la misión de la admiratio para fomentar el papel instructivo de epopeya y tragedia, a fin de mover a la imitación de los ejemplos de conducta propuestos. Homero ofreció por separado el modelo

\section{Gregorio Mayans, Rhetórica, II, p. 204.}

Ibid., I. p. 303.

Ibid., I. p. 303.

Puede verse Rinaldo Froldi, «La tradición trágica española según los tratadistas del siglo XVIII», Criticón, n. ${ }^{\circ} 23,1983$, pp. 132-157; y Antonio Mendoza Fillola, «Aspectos de la tragedia neoclásica española», Anuario de Filología, Universidad de Barcelona, n. ${ }^{\circ} 7,1981$, pp. 369-389. 
ejemplar de príncipe en las artes de la guerra -encarnado en el Aquiles de la Ilíada - y el modelo de príncipe en las artes de la paz - encarnado en el Ulises de la Odisea-, aunque, en opinión mayansiana, no dejó de cometer ciertas imperfecciones en una y otra obra. Homero agotó, por así decirlo, la invención poética, como minucioso observador de las acciones humanas y las cosas naturales, y como profundo conocedor de todas las ciencias y artes. El mantuano, por tanto, sólo podía imitarlo. Siguiendo a Scalígero, juzga Mayans que Virgilio, en su Eneida, sintetizó los dos personajes de Homero en uno solo, fecundando su imitación con gran entendimiento, un «conocimiento de los estudios más útiles ${ }^{33}$ y una profunda y detallada lectura de los autores griegos y latinos, observando - y copiando, cuando lo creía conveniente - lo mejor de cada uno en la invención, composición y expresión. La imagen que dibuja del héroe virgiliano es curiosa porque no deja de parecer el retrato de un monarca -ilustrado, por qué no-ideal: Eneas es valiente, pero no belicoso, justo, amante de su patria, respetuoso con las cosas sagradas, trabajador, equilibrado repartidor de premios, remiso en los castigos, señor de unos vasallos contentos y obsequiosos. No silencia Mayans el defecto de invención que representa poner juntos a Dido y Eneas, quienes vivieron tiempos diferentes, pero defectos tan pequeños como ése en nada disminuyen la magnitud de la obra. Al lado de los dos gigantes de la antigüedad, sólo La Araucana, La Austríada y el Montserrate -entre los españoles- merecen ser considerados como poemas épicos ${ }^{34}$. En cuanto a los trágicos, sólo Sófocles y Eurípides le parecen dignos de ser leídos con aprovechamiento, mientras que las obras trágicas de Séneca le parecen muy inferiores, tanto por la proliferación de sentencias agudas como por la oscuridad de su dicción.

La narración de la epopeya debe ser:

sabia, sublime, adornada de Episodios nacidos del mismo asunto, i muy agradables, i de hermosas Descripciones, i sobre todo, admirable, i deleitosamente provechosa ${ }^{35}$,

justificándose plenamente el comienzo ex abrupto, puesto que, debido a su extensión, así se facilita la lectura. Por su parte, la narración de la tragedia debe ser:

33 Gregorio Mayans, Vida de Publio Virgilio Marón, p. 27.

34 Gregorio Mayans, Vida de Miguel de Cervantes, p. 158.

35 Gregorio Mayans, Rhetórica, I, p. 345. 
sentenciosa, engrandecedora de las cosas sin afectación, i sin faltar al decoro útilmente afectuosa, ilustre ${ }^{36}$.

Respecto a la comedia, escribe:

La Comedia, que es una imitación de la vida de los Ciudadanos más versados en negocios, i por esso más cautos, es una representación de la vida civil con artificiosa conexión, atadura $i$ solución ingeniosa, a fin de que la admiración del oyente sea mayor, el deleite de la salida más agradable, $i$ assí la enseñanza se insinúe mejor en el ánimo ${ }^{37}$.

$\mathrm{Si}$ al referirse a la tragedia no había hecho alusión alguna al cambio de fortuna de los protagonistas, sí lo menciona al hablar de la comedia, en cuyo desenlace - desatamiento- se pasa «de la felicidad, a la infelicidad, o al contrario» ${ }^{38}$. La conexión entre los acontecimientos y su desenlace coadyuva a aumentar la admiración hacia el asunto de la obra. Parece como si en ciertos aspectos hubiera un deslizamiento de ideas que van de la tragedia a la comedia, haciendo más hincapié en los elementos puramente dramáticos al tratar de la comedia. A diferencia de Luzán, que insiste en que:

todo sea dirigido a utilidad: y entretenimiento del auditorio, inspirando insensiblemente amor a la virtud y aversión al vicio ${ }^{39}$,

Mayans enfatiza los recursos que intensifican la admiratio, no como meta por sí misma, sino como vía para reforzar el deleite y la enseñanza. La narración de la comedia, en consecuencia, debe ser «ingeniosa, instructiva, discreta, urbana» ${ }^{40}$.

Conviene hacer un inciso para subrayar que, en el caso concreto del teatro, Mayans no insiste ni desarrolla especialmente la llamada doctrina de las unidades, aunque sí repite por doquier que la narración de los diversos géneros ha de ser breve, clara, verosímil y decorosa. Sin embargo, como en otros aspectos, su asimilación de las ideas aristotélicas y horacianas aflora puntualmente, como surgida de un indistinto sentido común. Así, en lo que a las unidades atañe, escribe que los episodios de la tragedia y de la comedia deben ser menos amplios que los

Ibid., I, pp. 345-346.

Ibid., I, p. 305.

Ibid. , I, p. 305.

Ignacio de Luzán, La Poética, ed. de R. P. Sebold, Barcelona, Labor, 1977, p. 528.

Gregorio Mayans, Rhetórica, I, p. 346. 
de la epopeya, porque su asunto «está ceñido a la acción de un día» ${ }^{41}$, o aún más explícito escribe sobre Lope, apostillando sobre su Arte nuevo de hacer comedias, «si merece tal nombre un razonamiento académico tan contrario a ella» ${ }^{42}$. $\mathrm{O}$, con mayor claridad:

Llegó a decir Lope que las nuevas circunstancias del tiempo pedían nuevo género de comedias, como si la naturaleza de las cosas fuesse mudable por qualesquiera accidentes ${ }^{43}$,

donde pone de manifiesto su creencia íntima en la validez universal y atemporal de las reglas del arte $\mathrm{y}$, por tanto, de las unidades.

Distingue Mayans entre bucólica, «representación de la vida del Labrador perfecto» ${ }^{44}$, que ha de narrarse «hermoseada de semejanzas del campo, i de bellezas naturales» ${ }^{45}$, y la égloga, «representación de la vida pastoril» ${ }^{46}$ que debe ser «naturalmente discreta, hermoseada de semejanzas pastoriles» ${ }^{47}$, y sobre la que reproduce el párrafo que Herrera dedica a la égloga en sus Anotaciones, discutiendo la afirmación del Divino de que la égloga trate sobre todo de los amores entre pastores, sugiriendo la búsqueda de temas eglógicos en la vida de los santos pastores de la antigüedad (léase: santos padres, profetas, etc.). Teócrito, Virgilio y Garcilaso son - cada uno en su momento- los más perfectos autores de églogas, en tanto que las de Encina, siguiendo en esto la opinión de Herrera, le parecen «infacetíssimas» ${ }^{48}$.

La sátira es «una representación de los vicios humanos» ${ }^{49}$, que puede ser personal o fingida, siendo esta última más útil para hacer «odiosa la reprehensión» ${ }^{50}$, y cuya narración debe ser característica «de las

Ibid., I, p. 347.

Gregorio Mayans, Vida de Miguel de Cervantes, p. 68.

Ibid., p. 66.

Gregorio Mayans, Rhetórica, I, p. 304.

Ibid., I, p. 346.

Ibid., I, p. 304.

Ibid., I, p. 346.

Ibid., I, p. 305.

Ibid., I, p. 307.

Ibid., I, p. 307. 
costumbres humanas, i cortésmente reprehensiva» ${ }^{51}$. Destacaron en su cultivo, entre los antiguos, Horacio, Juvenal y Persio; y, entre los castellanos, Torres Naharro -en su Propaladia- y Bartolomé Leonardo Argensola. Pero así como la sátira sólo tiende a manifestar la censura, el entremés es:

Una agradable imitación de las acciones ridículas de alguna Persona para mover a la enmienda de las costumbres por el justo temor de la burla ${ }^{52}$,

quejándose de lo ridículos que resultan muchos entremeses, cuya narración debe ser «burlona, festiva, placentera» ${ }^{53}$, y señalando la notable diferencia de efecto que produce un entremés leído o visto representar ${ }^{54}$.

Dos géneros reciben, sin embargo, un tratamiento más extenso en la Rhetórica, a expensas de otros géneros algo decaídos en el siglo anterior: el diálogo y el apólogo.

El diálogo es para Mayans, como recuerda Aguilar Piñal:

una conversación fingida con versimilitud i decoro a fin de enseñar agradablemente ${ }^{55}$,

o, como escribe en otro lugar:

una representación del más perfecto modo de manifestar los pensamientos por medio de una fingida conversación ${ }^{56}$.

Antes ya de publicar la Rhetórica, Mayans había manifestado concretamente la utilidad potencial que le atribuye al género escribiendo y publicando en 1733 El Orador Christiano en forma de tres diálogos. No puede ser ajeno a su afición a la forma dialógica la común práctica humanista y renacentista del género ${ }^{57}$ (Erasmo, con sus Colloquia marca un hito, y con él emparentan los Valdés y un largo etcétera).

51 Ibid., I, p. 346.

52 Ibid., I, p. 311.

53 Ibid., I, p. 346.

54 Gregorio Mayans, Vida de Miguel de Cervantes, pp. 168-169.

55 Gregorio Mayans, Rhetórica, II, pp. 460-461.

56 Ibid., I, p. 307.

57 Vid. David Marsh, The Quattrocento Dialogue. Classical Tradition and Humanist Innovation, London, Harvard Univ. Press, 1980. 
El diálogo debe tender a imitar con la mayor perfección posible «la idea de la más perfecta conversación» ${ }^{58}$ que se caracteriza, en palabras del valenciano, por «la verdad, el buen méthodo, la claridad, la brevedad, la gracia, i el buen modo de decir» ${ }^{59}$. El estilo del diálogo debe ajustarse a su carácter, es decir, ha de ser similar al de una «juiciosa conversación ${ }^{60}$. El lenguaje que ha de emplearse en un diálogo no debe ser poético, lo que atenta contra la esencia misma de la prosa, y su estilo habría de ser:

puro, i claro, más natural que artificioso, o por mejor decir, artificiosamente natural, i sobre todo instructivo ${ }^{61}$,

no debiendo participar en él nunca más de cuatro personajes, y mejor tres que cuatro, pues un número excesivo de interlocutores perturba la atención del lector, impidiendo con ello que el diálogo actúe con eficacia. Mayans no es sólo el primero que, en el siglo dieciocho, teoriza las ventajas del diálogo como género especialmente apto para los fines de utilidad e instrucción, sino que en El Orador Christiano propone un ejemplo práctico - centrado en un tema que preocupará a los ilustrados: la predicación barroca - sobre sus posibilidades. Sin entrar en detalle a valorar sus cualidades literarias o estilísticas, el diálogo está concebido con orden, las ideas afloran coherentemente y su lenguaje es claro y preciso. Su estructura es la usual en los diálogos renacentistas, con un personaje central que expone lo fundamental del tema o los temas que se tratan, y otro - u otros - que plantean dudas, apostillan, comentan, ensalzan y aun discrepando acaban por reconocer y aceptar la autoridad intelectual y racional de aquél.

El otro género al que Mayans presta especial atención es el apólogo:

El Apólogo es una ficción alegórica de cosas absolutalmente imposibles tratadas, como si fueran verdaderas, para instruir el ánimo con imaginarios pero doctrinales egemplos ${ }^{62}$.

Como puede verse, añadiendo aquí que se trata de cosas imposibles, es la misma definición - o prácticamente la misma- que antes 
daba de lo que entiende por fábula, y así lo reconoce él mismo páginas más adelante, cuando se refiere a que Fedro y Esopo añadieron a la fábula el aviso a fin de clarificar el sentido de aquélla. El apólogo se compone, pues, de narración y aviso, aunque no tienen por qué ir juntos, puesto que la narración por sí sola puede ser «instructiva acomodándose a la naturaleza de las cosas» ${ }^{63}$. Aunque por su modo de narrarse debe ser «sencilla [...], instructiva, agradable» ${ }^{64}$, desde Esopo y Fedro el género ha mostrado su capacidad para ser tratado con mayor adorno, como en el caso de Aldana, o con mayor erudición, en B. L. Argensola o Mateo Alemán.

En síntesis, Mayans, retomando ideas de la tradición retórico-poética clásica (antigua y renacentista), pergeña unas páginas en las que sobresalen dos rasgos: por una parte, la plena asunción del precepto horaciano delectare et prodesse, a cuyo campo de influencia no escapa género alguno de escritura; por la otra, cómo los principios que considera válidos para todas las manifestaciones de la prosa - claridad, naturalidad, etc. - tienen también validez para los diversos géneros poéticos.

De este modo, y pese a la brevedad de las páginas que le dedica, contribuye a la corriente que atravesará todo el siglo, y cuyos frutos más específicamente literarios sólo se recogerán en las últimas décadas de la centuria.

\section{El dieciocho, ¿un siglo prosaico?}

Se puede admitir la calificación de prosaico que se ha querido otorgar al siglo dieciocho siempre que, jugando con las palabras, nos atengamos a su sentido literal. El siglo dieciocho es el siglo de la prosa, y el siglo en que se fragua la prosa moderna, en la acción combinada de un mayor conocimiento y depuración de los usos lingüísticos, de criterios uniformes para la ortografía y de una abierta oposición a la poetización de la prosa, no tanto por insensibilidad como por la acuciente necesidad de forjar y templar una lengua que permita tratar con claridad y eficacia cualquiera de los múltipes temas que ofrecen las innovaciones del siglo.

63 Ibid., I, p. 327.
64 Ibid., I, p. 346. 
No es prosaico en el sentido de negación de la poesía. Que haya muchos o pocos poetas, que haya pocos o menos grandes poetas no tiene nada que ver con las ideas literarias que dominan el pensamiento de intelectuales y artistas. En el siglo XVI hay países que cuentan con una pléyade de poetas y otros que apenas los cuentan con los dedos de una mano: lo mismo ocurre en todos los momentos de la historia. Una eclosión creadora en todas las lenguas cultas y del mismo calibre sería poco menos que imposible y ofensivo. Pero una época que contara con Cadalso, Jovellanos, Meléndez o Moratín no puede considerarse, en modo alguno, como prosaica. Otro asunto, discutible, por supuesto, es el carácter de esa poesía, su temática dominante o los recursos estilísticos que se ponen en juego. Salvando las distancias, al juzgar la «poesía social» española de los cincuenta de nuestro siglo no se puede calificar de prosaica la época sólo porque numerosos poetas convergieran en tratar temas y problemas similares, o incluso porque su lenguaje y su estilo presentaran rasgos comunes. El punto fundamental es que no todos llegan a ser poetas y que, sin embargo, entre ellos hay algunos excelentísimos poetas.

Auge de la prosa, extensión de su radio de acción a campos nuevos, ejercicio de la lengua española en dominios que se van abriendo o que van profundizando adquisiciones y hallazgos anteriores, puesta a punto de una manera de hablar y escribir que no sólo servirá para redactar tratados de botánica, geografía, economía o política, sino que también abrirá las puertas para la prosa de un Larra o de los primeros verdaderos novelistas del XIX. La defensa de la prosa no puede ser objeto de censura en términos peyorativos. Y más aún, cuando, como es patente en el caso de Mayans, el combate por depurar la prosa castellana de la ganga acumulada en los estertores barrocos, por imponer criterios de claridad, de pureza, de propiedad y de naturalidad va unido a una constante llamada de atención para que en el altar de esos valores no se sacrifiquen los altos quilates de la elocuencia. La bandera de una prosa equilibrada entre la naturalidad y la claridad y los recursos estilísticos más variados y ricos: ése es el verdadero y único prosaísmo del siglo, al que Mayans contribuye decisivamente con su pensamiento, sus obras y su ejemplo. 